\title{
METODY WYKORZYSTYWANE PRZEZ POLSKICH KRYMINALISTYKÓW I ARCHEOLOGÓW PRZY EKSPLORACJI MOGIŁ - RÓŻNICE I ZBIEŻNOŚCI
}

SŁowA KLuCzowe: kryminalistyka, archeologia, mogiła, ekshumacja

KEYWORDs: forensics, archaeology, grave, exhumation

Z pozoru mogłoby się wydawać, że archeologia i kryminalistyka są dwiema odległymi i nie mającymi ze sobą wiele wspólnego gałęziami nauki. Gdyby jednak nieco dokładniej przyjrzeć się metodom postępowania przyjętym w obu dziedzinach może się okazać, że istnieją między nimi pewne podobieństwa.

Archeologia bada ślady działalności człowieka na przestrzeni dziejów, a na podstawie danych zebranych podczas prac terenowych i eksploracji stanowisk archeologicznych podejmuje się rekonstrukcji różnych aspektów życia ludzkiego z minionych epok. Istotną częścią tej pracy jest badanie cmentarzysk, które dają podstawy na wyciąganie wniosków co do obrzędowości pogrzebowej, a także niejednokrotnie dostarczają materiału zabytkowego pozwalającego na badanie historii kultury materialnej.

Przejawy aktywności człowieka stanowią również przedmiot zainteresowania kryminalistyki, jednak w tym przypadku chodzi o działalność przestępczą, czyli niezgodną z prawem. Głównym zadaniem tej nauki jest wykrycie przestępstwa oraz jego sprawcy. O ile archeologia zajmuje się badaniem dziejów, nierzadko bardzo odległych w czasie, o tyle kryminalistyka bada głównie sprawy współczesne (Trzciński 2005: 193).

Wzajemna współpraca archeologów i kryminalistyków wydaje się podejściem jak najbardziej słusznym, jeśli wyjdziemy z założenia, że groby stanowią antropogeniczne obiekty kulturowe - dlatego też najlepiej wykwalifikowanymi do ich badania naukowcami są właśnie archeolodzy, ze względu na duże doświadczenie na tym polu oraz odpowiednio wypracowane metody (Kola 2011: 
62). Współcześnie używany jest zresztą termin archeologia sądowa jako nazwa swego rodzaju specjalizacji archeologicznej znajdującej zastosowanie w pracy organów ścigania.

Różnice w podejściu do eksploracji mogił widoczne są już w literaturze przedmiotu. Archeolodzy zajmują się wydarzeniami sprzed lat, dokonują ekshumacji grobów zawierających najczęściej ludzkie szczątki w postaci szkieletu. Kryminalistyków dotyczą sprawy teraźniejsze w związku z czym dokonują oględzin zwłok i miejsca ich spoczynku, które wcale nie musi być jednoznaczne z grobem. Metody ekshumacji opisane są głównie w pracach archeologicznych, podręczniki kryminalistyki podają natomiast ogólne wytyczne odnośnie zabezpieczenia miejsca zdarzenia bez określenia jego charakteru (np. Mazepa 2009).

Na wstępie chciałbym zaznaczyć, że artykuł ma przede wszystkim dotyczyć badań polskich naukowców i rozwoju współpracy archeologów i kryminalistyków na gruncie rodzimym. Wszelkie zagraniczne przykłady jakie mogą pojawić się w tekście, posłużą tylko w celu podania egzemplifikacji ewentualnych metod, które mogą zostać wykorzystane przy eksploracji mogił.

\section{Pojęcia archeologit SĄDOWEJ, KRYMinalistyki, PODSTAWy PRAWNe UdZialu ARCHEOLOGA W CZYNNOŚCIACH PROCESOWYCH ORAZ NAUKI POMOCNICZE}

Archeologia sądowa jest dyscypliną naukową, która ma za zadanie wspierać postępowania prokuratorskie i sądowe. Metodyka badań archeologicznych znajduje zastosowanie podczas prowadzonych śledztw i dochodzeń w związku z popełnieniem lub podejrzeniem popełnienia przestępstwa. Tego typu sytuacje uznać można za podstawowy cel istnienia takiej dyscypliny, jednak z powodzeniem może się ona sprawdzić także w sprawach z zakresu prawa cywilnego, np. przy podziale nieruchomości i badaniu granic działki w momencie kiedy nie są one uchwytne inaczej niż np. poprzez wykopaliska lub inne, nieinwazyjne środki (Kawecki i in. 2013: 17-18).

W krajach Europy Zachodniej specjalizacja ta znana jest pod nazwą forensic archaeology. Archeologiczne metody eksploracji stanowisk, dokumentacji oraz sposobów identyfikacji pozyskanego materiału są tam stosowane od co najmniej lat 80 . XX w. w sprawach kryminalnych, a współpraca z kryminalistykami ma odpowiednio wypracowane i jasno określone podstawy metodologiczne (Trzciński 2005: 197-198; Kawecki i in. 2013: 23).

W Polsce omawiana dyscyplina jest jeszcze stosunkowo świeżym pojęciem. Z racji zajmowania się sprawami takimi jak poszukiwanie grobów masowych oraz pochówków pojedynczych ofiar zbrodni wojennych wkracza ona bardzo często $\mathrm{w}$ czasy najnowsze. Zapis w Ustawie $\mathrm{z}$ dnia 6 czerwca 1997 r. kodeksie karnym art. $105 \S 1$ stwierdza, że zbrodnie przeciwko pokojowi, ludzkości i przestępstwa wojenne nie ulegają przedawnieniu, co 
umożliwia prowadzenie dochodzeń w takich sprawach. Sprecyzowanie zakresu tej nowej dyscypliny może prowadzić do pewnych nieporozumień skutkiem czego możne być ona mylona np. $\mathrm{z}$ archeologią prawną (badającą pozostałości materialne dawnego wymiaru sprawiedliwości) lub też przestępczością przeciwko zabytkom archeologicznym (Kawecki i in. 2013: 15-16, 23).

Kryminalistyka powstała w XIX w. jako nauka pomocnicza dla prawa karnego. W początkach swojego istnienia, była ona najbardziej związana $\mathrm{z}$ medycyną sądową oraz antropologią. Zajmowała się identyfikacją zwłok, tworzeniem portretów pamięciowych osób poszukiwanych oraz zakładaniem pierwszych kartotek policyjnych z wykorzystaniem śladów daktyloskopijnych i rysopisów sprawców przestępstw. Z biegiem czasu dyscyplina ta usamodzielniła się poszerzając obszary swoich zainteresowań naukowych oraz wypracowując własne sposoby postępowania (Gruza i in. 2008: 15-18). Zgodnie z definicją, kryminalistyka jest nauką o metodach ustalania faktu przestępstwa, sposobu jego popełnienia, wykrywania sprawców i zapobiegania; dzieli się ona na 2 działy: taktykę i technikę kryminalistyczną (Encyklopedia... 1998: 140). W literaturze funkcjonują różne definicje tej dziedziny, na ogół jednak z uwzględnieniem wykorzystania metod i środków technicznych służących do wykrycia i zabezpieczenia śladów przestępstwa. Podstawowe funkcje tej nauki to: rozpoznawcza, wykrywcza, dowodowa, a także zapobiegawcza (Gruza i in. 2008: 19-25).

Udział archeologa w czynnościach procesowych jest oczywiście uwarunkowany odpowiednimi przepisami. Zawarte one zostały $\mathrm{w}$ Ustawie $\mathrm{z}$ dnia 6 czerwca 1997 r. kodeksie postępowania karnego. Artykuł 209 § 1 k.p.k. określa, że oględziny i otwarcie zwłok przeprowadza się w sytuacji, gdy zachodzi podejrzenie przestępnego spowodowania śmierci. Paragraf 3 tego artykułu mówi o tym, że oględziny zwłok przeprowadza się na miejscu ich znalezienia, a do czasu przybycia biegłego i prokuratora ich przemieszczanie lub poruszanie dozwolone jest tylko w konieczności. Zapis ten powiązany jest raczej ze współczesnymi sprawami kryminalnymi, w archeologii najczęściej mamy do czynienia z ekshumacją, o której traktuje art. 210 k.p.k. - w celu dokonania oględzin lub otwarcia zwłok prokurator lub sąd może zarządzić wyjęcie zwłok z grobu. Warto również zwrócić uwagę na różnicę w określeniu zwłoki, a szczątki ludzkie. Zgodnie z prawem te pojęcia nie są tożsame. Ich definicje znajdują się w Rozporządzeniu Ministra Zdrowia z dnia 7 grudnia 2001 r. w sprawie postepowania ze zwłokami i szczątkami ludzkimi (Dz.U. $2001 \mathrm{Nr}$ 153, poz. 1783). Paragraf 2 tego rozporządzenia określa zwłoki jako ciała osób zmarłych i dzieci martwo urodzonych. Zgodnie z $\S 8$ szczątki ludzkie są zdefiniowane jako:

- popioły powstałe w wyniku spopielenia zwłok;

- pozostałości zwłok, wydobyte przy kopaniu grobu lub w innych okolicznościach;

- części ciała ludzkiego odłączone od całości. 
Zgodnie z art. 193 § 1 k.p.k. jeśli stwierdzenie okoliczności mających istotne znaczenie dla rozstrzygnięcia sprawy wymaga wiadomości specjalnych, zasięga się opinii biegłego lub biegłych. Według $§ 2$ można w tym celu zwrócić się też do instytucji naukowej lub specjalistycznej. Zapisy te umożliwiają, w przypadku śledztw uwzględniających czynności związane z eksploracją mogił, skonsultowanie się z archeologiem. Zgodnie z art. 195 k.p.k. do pełnienia tego typu czynności obowiązany jest nie tylko rzeczoznawca sądowy, lecz także każda osoba, o której wiadomo, że ma odpowiednią wiedzę w danej dziedzinie. Sądy okręgowe prowadzą listy biegłych powoływanych do wydawania opinii w różnych sprawach, jednak wyżej wymieniony artykuł umożliwia wezwanie tzw. biegłego ad hoc, spoza listy, jeśli jego wiedza może zostać wykorzystana $\mathrm{w}$ toku postępowania. Udział archeologa może mieć też nieco inną formę. Zgodnie z art. $205 \S 1$ k.p.k. jeśli dokonanie oględzin bądź też przesłuchania przy użyciu urządzeń technicznych umożliwiających przeprowadzenie tych czynności na odległość, eksperymentów, ekspertyz, zatrzymania rzeczy lub przeszukania wymaga czynności technicznych, w szczególności takich jak wykonanie pomiarów, obliczeń, zdjęć, utrwalenie śladów, można do udziału w nich wezwać specjalistów. Zapis ten jest szczególnie ważny, gdyż umożliwia wykorzystanie wiedzy i doświadczenie archeologa w pracach terenowych związanych z poszukiwaniem i ewentualną ekshumacją mogił. Według § 3 po dokonaniu wszelkich niezbędnych czynności z udziałem specjalistów należy sporządzić protokół, w którym wskazuje się ich imiona i nazwiska, specjalność, miejsce zamieszkania, miejsce pracy i stanowisko oraz rodzaj i zakres czynności wykonanych przez każdego z nich. Artykuł 206 k.p.k. określa, że do specjalistów stosuje się te same przepisy co do biegłych poza art. 194, 197, 200 i 202 k.p.k. Artykuł 206 k.p.k. zezwala także na przesłuchanie specjalisty w charakterze świadka.

Archeologia i kryminalistyka powstałe początkowo jako nauki pomocnicze, z czasem usamodzielniły się i uległy przekształceniu w odrębne, interdyscyplinarne dziedziny. To znaczy, że specjaliści obu kierunków wykorzystują w swojej pracy osiągnięcia i metody wielu innych nauk. Przy poszukiwaniu i eksploracji mogił szczególne miejsce zajmują m.in.:

- Antropologia - nauka zajmująca się przede wszystkim problematyką genezy gatunku ludzkiego oraz jego ewolucji na przestrzeni dziejów (Ławecka 2010: 181-182).

- Medycyna sądowa - eksploracja mogił, zarówno w archeologii jak i kryminalistyce siłą rzeczy wiąże się z dokonywaniem oględzin zwłok ludzkich lub szczątków kostnych jakie po nich zostały. Badania takie przeprowadza się m.in. w celu ustalenia przyczyn śmierci ofiary, określenia czasu zgonu, rodzaju odniesionych obrażeń czy też identyfikacji zwłok (Kawecki i in. 2013: 87-93, 112). 
- Geofizyka - nauka traktująca Ziemię jako ciało fizyczne, zajmująca się wszelkimi zjawiskami i procesami fizycznymi, które zachodzą obecnie lub miały miejsce w przeszłości geologicznej we wszystkich geosferach (Encyklopedia... 1997: 307).

- Entomologia sądowa - czyli badania owadów żerujących na zwłokach w celu oszacowania minimalnego czasu, jaki mógł upłynąc od chwili śmierci organizmu. Metoda znajdująca szersze zastosowanie raczej w przypadku postępowania karnego (Frątczak-Łagiewska 2016: 22).

Zasadniczą różnicą między badaniami archeologicznymi, a kryminalistycznymi oględzinami miejsca zdarzenia, jest to, że szczątki ludzkie pozyskane przez archeologów badane są później na ogół przez antropologów, natomiast w trakcie śledztw i dochodzeń zajmują się tym lekarze medycyny sądowej (co niekoniecznie wyklucza udział antropologa w charakterze biegłego).

\section{METODYKA EKSPLORACJI MOGIL W UJĘCIU ARCHEOLOGICZNYM I KRYMINALISTYCZNYM}

Gdyby przyjrzeć się bliżej sposobom postępowania w przypadku badań archeologicznych i kryminalistycznych, można zauważyć między nimi wiele podobieństw. Obie dyscypliny zajmują się badaniem i rekonstruowaniem przeszłości na podstawie materialnych śladów, $\mathrm{w}$ archeologii określanych jako materiał zabytkowy, a w kryminalistyce jako materiał dowodowy. W kryminalistyce funkcjonuje tzw. reguła siedmiu złotych pytań - jest to podstawowy zestaw zagadnień wymagających wyjaśnienia, który dopasowuje się właściwie do każdej sprawy kryminalnej: Co? Gdzie? Kiedy? W jaki sposób? Dlaczego? Jakimi środkami? Kto? (Gruza i in. 2008: 205-206). Łatwo zauważyć, że podobny zestaw pytań dotyczących okoliczności zdarzenia, sposobu działania sprawcy i motywów jego postępowania można zastosować w przypadku badania stanowisk archeologicznych. Jeśli weźmiemy pod uwagę np. miejsce masowych pochówków ofiar zbrodni ludobójstwa, pytania te i elementy, do których one się odnoszą będą właściwie identyczne. W obu dyscyplinach stawia się pewną hipotezę (wersję kryminalistyczną), a następnie weryfikuje w trakcie badań. Zarówno w archeologii jak i kryminalistyce ważne jest zachowanie obiektywizmu, tak aby nie dopasowywać faktów potwierdzanych przez ślady materialne do postawionej przez siebie tezy. W przypadku dochodzeń kryminalnych nieumiejętne podejście do sprawy może skutkować niewykryciem sprawcy i umorzeniem śledztwa, a w archeologii błędna interpretacja może wpłynąć na zafałszowanie obrazu historii. Zebrany w trakcie badań materiał zabytkowy bądź dowodowy musi być odpowiednio zabezpieczony, a następnie poddaje się go często badaniom laboratoryjnym i specjalistycznym ekspertyzom. Niezwykle istotnym elementem zarówno czynności procesowych, jak i naukowych badań 
jest także sporządzenie stosownej dokumentacji. Tu także możemy dostrzec podobieństwa, obie dyscypliny wykorzystują przede wszystkim dokumentację opisową, rysunkową i fotograficzną (Trzciński 2005: 193-195; Kawecki i in. 2013: 19-21). Poniżej zostaną przedstawione najbardziej powszechne metody stosowane przy eksploracji stanowisk z ludzkimi pochówkami.

\section{LOKALIZACJA MIEJSCA ZDARZENIA}

Wszelkie prace należy rozpocząć od zlokalizowania w terenie miejsca zdarzenia, na którym będziemy prowadzili swoje prace i określenia jego zasięgu. Termin miejsce zdarzenia użyty jest nieprzypadkowo. Pochodzi on z terminologii kryminalistycznej, nie oznacza jednak jednoznacznie miejsca dokonania przestępstwa. Pojęcie to obejmuje swoim zakresem miejsca przygotowań sprawcy do popełnienia czynu, drogi dojścia i ucieczki, wreszcie miejsce wystąpienia skutków działań dokonanych przez sprawcę (Mazepa 2009: 13). Jako takie zaś, może równie dobrze być zastosowane do określenia stanowiska terenowego, na którym swoją pracę wykonuje archeolog, zwłaszcza archeolog sądowy z racji powiązań z czynnościami procesowymi.

Przede wszystkim należy mieć przygotowany odpowiedni plan działania, zawierający m.in. harmonogram prowadzonych badań, sprzęt niezbędny do ich przeprowadzenia oraz wykaz osób odpowiedzialnych za poszczególne elementy. Przed rozpoczęciem jakichkolwiek prac w terenie, należy się zapoznać się z osobowymi i archiwalnymi źródłami informacji, czyli wszelkimi dokumentami, przekazami ustnymi dotyczącymi interesującego nas problemu, a także przestudiować mapy terenu, po którym będziemy się poruszać. Jeśli istnieje taka możliwość, dobrze jest wziąć pod uwagę inne materiały, takie np. jak fotografie lotnicze i satelitarne. Czynności tego typu można określić jako wywiad archeologiczny (Sojka 1977: 217; Kawecki i in. 2013: 117). Podobnie postępują również funkcjonariusze i biegli biorący udział w czynnościach procesowych dotyczących sprawy kryminalnej - studiują akta sprawy i materiały operacyjne policji oraz analizują materiały z przesłuchań świadków. Źródła informacji w postaci przekazów pisemnych, a zwłaszcza ustnych (zeznania świadków) należy jednak traktować z pewnym dystansem. Szczególnie przy badaniach archeologicznych, które dotyczą wydarzeń dość odległych w czasie, informacje takie mogą być mało precyzyjne lub po prostu błędne. Zbierane współcześnie zeznania dotyczące np. okresu II wojny światowej będą najprawdopodobniej niezbyt dokładne ze względu na niedoskonałość ludzkiej pamięci - po tylu latach wspomnienia mogą zwyczajnie rozmijać się z rzeczywistością (Kawecki i in. 2013: 118-120).

Przed rozpoczęciem prac terenowych należy rzecz jasna dokonać lokalizacji miejsca zdarzenia w terenie. Oczywiście w przypadku śledztwa prowadzonego w sprawie wydarzeń bieżących, miejsce to jest często już znane i technicy kry- 
minalistyki przystępują bezpośrednio do oględzin. Jednak przy zbrodni dokonanej w dalszej przeszłości, tak jak na wykopaliskach archeologicznych, trzeba się liczyć z koniecznością wyznaczenia odpowiedniego terenu i przeszukania go w celu odnalezienia materialnych śladów powiązanych $\mathrm{z}$ interesującą nas sprawą. Warto zacząć od szkiców, map i planów danego obszaru. Mogą one być tworzone na bieżąco $\mathrm{w}$ związku z podejmowanym przedsięwzięciem lub powstałe już wcześniej, z innym założeniem, ale nadające się do wykorzystania przy poszukiwaniach. Należy zwrócić uwagę na szczegółowość takich dokumentów, ich zgodność z rzeczywistą topografią terenu, skalę w jakiej zostały wykonane i w jakim stopniu są opisane. Pozwolą one zorientować się jak wygląda miejsce przyszłych prac, jakie można tam napotkać przeszkody - teren może być gęsto zalesiony lub częściowo zurbanizowany. Plany geologiczne będą przydatne $\mathrm{w}$ celu określenia $\mathrm{z}$ jakimi rodzajami gleb będziemy mieli do czynienia, co z kolei ułatwi dobór odpowiednich metod geofizycznych przy prospekcji terenowej. Jeśli zajmujemy się wydarzeniami, np. sprzed kilkudziesięciu lat, warto porównać mapy współczesne z archiwalnymi. Nowoczesne programy komputerowe umożliwiają porównanie takich obrazów, odpowiednie wyskalowanie ich i nałożenie na siebie. To uwidacznia nam jakie zmiany mogły zajść na danym obszarze na przestrzeni lat, ułatwia wskazanie fragmentów krajobrazu, które mogą już nawet nie istnieć (Kawecki i in. 2013: 120-121).

Niezwykle użyteczne okazują się także fotografie lotnicze i satelitarne - oczywiście wykonanie takich zdjęć na potrzeby bieżących badań byłoby dość kosztowne, wobec czego wykorzystuje się materiał powstały już wcześniej w innych celach. Dzięki nim można dostrzec charakterystyczne zmiany w ukształtowaniu terenu mogące świadczyć o istnieniu tam wcześniej jakiegoś obiektu. Zwraca się ponadto uwagę na różnice w zabarwieniu gruntu wskazujące na inną wilgotność lub skład gleby, jak również miejsca koncentracji materii organicznej. Ważne są nawet takie szczegóły jak roślinność na wyznaczonym obszarze i intensywność w jakiej ona tam występuje (Kawecki i in. 2013: 122). Dobrym przykładem wykorzystania fotografii lotniczych było dochodzenie w Miednoje z 1991 roku gdzie ekipa badawcza mogła dokonać analizy porównawczej zdjęć terenu wykonanych przez Luftwaffe w roku 1942 z materiałem dostarczonym przez Rosjan wykonanym już na początku lat 90 (Głosek, $W$ cieniu Lasu ...: 21).

Inną, nowoczesną metodą rozpoznania terenowego jest tzw. LiDAR (Light Detection and Ranking), czyli lotniczy skaning laserowy. Metoda ta stosowana jest na razie dość rzadko ze względu na wysokie koszty. Kamery termowizyjne zainstalowane na samolotach lub satelitach rejestrują za pomocą promieni podczerwonych niewielkie zmiany (rzędu dziesiętnych części stopnia Celsjusza) w temperaturze badanego gruntu, co pozwala na uchwycenie zmian dokonanych w jego strukturze i potencjalnie istniejących tam obiektów, które charakteryzują się innymi właściwościami termicznymi niż ich otoczenie. Metoda ta sprawdzi- 
ła się w Irlandii gdzie Niezależna Komisja do Poszukiwania Szczątków Ofiar (ICLVR) wykorzystała lotniczy skaning laserowy przy lokalizacji miejsc ukrycia zwłok osób uznanych za zaginione, często ofiar Irlandzkiej Armii Republikańskiej (Kawecki i in. 2013: 126-127).

Bardzo powszechnie stosowaną metodą prospekcji archeologicznej służącą do lokalizacji stanowiska, na którym prowadzone będą prace są badania powierzchniowe. Polegają one na dokładnym przeszukaniu wyznaczonego obszaru pod względem śladów obecności działalności człowieka uwidaczniających się na powierzchni ziemi. Mogą to być np. zachowane fragmenty budowli lub nietypowo zmieniające się ukształtowanie terenu (wzniesienia układające się w kształt wałów grodziska, zagłębienia będące fosami lub kurhany). Interesujących informacji dostarczają także zmiany $\mathrm{w}$ wegetacji roślin. Na ogół w zasypiskach grobów, rowów i wszelkich wykopów występuje większe nagromadzenie wilgoci i materii organicznej, co powoduje też bujniejszy wzrost roślinności w tych miejscach oraz intensywniejszą jej barwę. Zależnie od sytuacji, jeśli badane jest miejsce katastrofy samolotu, czy obszar, na którym odbyła się jakaś egzekucja, można natknąć się na pojedyncze przedmioty tkwiące na powierzchni (odpowiednio - fragmenty samolotu lub łuski pocisków wskazujące na użycie broni palnej). Również orka prowadzona na danym terenie może przyczynić się do przypadkowego ujawnienia przedmiotów o wartości zabytkowej. We współczesnej archeologii badania powierzchniowe znacznie zyskały na znaczeniu. Często są one oddzielnymi projektami badawczymi, bez kontynuacji w postaci prac wykopaliskowych, choć na niektórych stanowiskach uzupełnia się je poprzez przeprowadzenie badań sondażowych lub nawet szerzej zakrojonych wykopalisk. Celem takich badań jest m.in. zwrócenie uwagi na tzw. krajobraz archeologiczny, czyli kontekst $\mathrm{w}$ jakim znajduje się dane stanowisko - jego powiązania $\mathrm{z}$ najbliższym otoczeniem (Ławecka 2010: 41-42, 44; Kawecki i in. 2013: 128, 132).

W kryminalistyce, odpowiednikiem archeologicznych badań powierzchniowych są tzw. ogólno-orientacyjne oględziny miejsca zdarzenia, podczas których dokonuje się przeglądu odpowiedniego obszaru w celu wyznaczenia jego granic, dopasowania planu do zaistniałej sytuacji i doboru dalszych metod pracy. Oględziny służą odnalezieniu i zabezpieczeniu wszelkich śladów kryminalistycznych, które w dalszych etapach postępowania będą stanowić materiał dowodowy (Gruza i in. 2008: 203). Działania archeologów i kryminalistyków są tu właściwie bardzo podobne. Zasadniczo przyjmuje się, że obszar zaplanowany do badań powinien mieć wstępnie poszerzone granice, które później, w miarę zdobywania dokładniejszych danych będą stopniowo zawężane. Rozpoznanie terenu o dużej powierzchni dobrze jest zacząć od podzielenia go na mniejsze sektory i wyznaczenia siatki arowej, czyli systemu kwadratów o powierzchni $100 \mathrm{~m}^{2}$. W razie potrzeby można oczyścić okolicę ze zbędnej roślinności i śmieci mogących utrudnić dostrzeżenie istotnych śladów (Kawecki i in. 2013: 
127-129). Następnie dokonuje się prospekcji terenowej. Sposobem na stworzenie dobrej dokumentacji z badań powierzchniowych jest planigrafia. Polega ona na nanoszeniu położenia odkrytych na powierzchni znalezisk na przygotowany wcześniej plan stanowiska (Ławecka 2010: 46). Ekipy dochodzeniowe korzystają z kamer i aparatów z wbudowanymi systemami GPS, które pozwalają na łatwe nałożenie obrazu na zdjęcia lotnicze i satelitarne. Wszystko to umożliwia łatwe oznaczenie ewentualnych znalezisk w wydzielonych sektorach poszukiwań i skoordynowanie działań całej ekipy. W celu wykorzystania najnowocześniejszych i najskuteczniejszych metod powołuje się biegłych, którzy mają w tym zakresie większą wiedzę niż członkowie zespołu dochodzeniowo-śledczego (Stojer-Polańska i in. 2015: 6).

Jedną z metod przydatnych przy lokalizowaniu zwłok, jednak w Polsce wykorzystywaną wyłącznie na potrzeby kryminalistyczne, jest udział psów osmologicznych w poszukiwaniach. Zwierzęta te pełnią służbę w policji, szkolone są w różnych specjalizacjach m.in. do badań osmologicznych na potrzeby pionu kryminalnego, a także do wyszukiwania zapachu zwłok ludzkich. Pies, mimo doskonale rozwiniętego zmysłu węchu ma jednak również swoje ograniczenia. Na jego pracę mogą mieć wpływ np. warunki atmosferyczne: opady, wiatr, różnice temperatur, stopień nasłonecznienia. Znaczenie ma także rodzaj podłoża lub liczba osób, która mogła przemieszczać się po danej drodze zapachowej. Również zapach innego zwierzęcia może prowadzić do dezorientacji i zgubienia śladu (zapach ten będzie bardziej atrakcyjny i właśnie za nim podąży zwierzę) (Mazepa 2009: 222, 228, 246). Psy osmologiczne można ponadto wyszkolić w poszukiwaniu ludzkich szczątków zakopanych w ziemi (rozkładające się ciała lub szkielety). W pewnych przypadkach zwierzęta te potrafią wykryć szczątki zdeponowane przed dwudziestoma lub więcej laty. W krajach zachodnich ten sposób poszukiwań jest w użyciu, podejmuje się w tym celu współpracę również z antropologami (Rebmann i in. 2000: 15-16, 135-137). Oczywistym staje się, że archeolodzy nie korzystają z tej metody ponieważ nie dysponują odpowiednio wyszkolonymi psami.

Badania powierzchniowe nie zawsze muszą dostarczyć konkretnych wyników. Mogą one pozwolić na określenie zasięgu obszaru na jakim będą prowadzone poszukiwania, ale w sytuacji, gdy na powierzchni gruntu nie będzie jednoznacznych śladów wskazujących na miejsce ukrycia zwłok należy skorzystać z geofizycznych metod badawczych. Są one powszechnie wykorzystywane zarówno w archeologii jak i kryminalistyce (Kawecki i in. 2013: 134-135). Najpowszechniejsze $\mathrm{z}$ nich to:

- metoda elektrooporowa;

- metoda magnetyczna;

- metoda elektromagnetyczna;

- wykrywacze metali. 
Wyżej przedstawione sposoby lokalizacji miejsca zdarzenia są metodami nieinwazyjnymi. W celu potwierdzenia uzyskanych dzięki nim wyników należy przeprowadzić badania sondażowe wymagające ingerencji w grunt (Lawecka 2010: 62-72; Stojer-Polańska i in. 2015: 4-6). Mogą to być np. odwierty wykonywane przy użyciu świdra geologicznego. Świder tego typu może sięgnąć do kilku metrów w głąb ziemi. Zakończony jest strzemiączkiem, w którym po wyjęciu z odwiertu znajduje się próbka gleby. Poddaje się ją oględzinom pod względem zmian morfologicznych w stratygrafii warstw powstałych w wyniku działalności człowieka. Po obejrzeniu zawartości strzemiączka w pewnej odległości wykonuje się następny odwiert, aby oszacować wielkość obiektu, z jakim mamy do czynienia. Metoda ta ma jednak swoje wady - w przypadku natknięcia się na materiał zabytkowy, świder może go uszkodzić. To samo może stać się z ludzkimi szczątkami, co niekiedy wzbudza sprzeciw wobec tej metody wśród osób postronnych (Kawecki i in. 2013: 145-146, 149). Pomysł wykonywania odwiertów sondażowych w miejscach ukrycia ofiar zbrodni wojennych wyszedł właśnie od archeologów. Ta metoda została zastosowana w 1991 r. w Miednoje oraz w czasie późniejszych badań w Katyniu. Ekipa dochodzeniowo-śledcza prowadząca prace ekshumacyjne w Miednoje początkowo odnosiła się do niej $\mathrm{z}$ niechęcią, jednak wyniki jakie przynosiła spowodowały upowszechnienie się jej na tego typu stanowiskach (Głosek 1996: 259-266). Próbki gruntu pochodzące z odwiertów warto również poddać badaniom fizykochemicznym. Stosuje się tu tzw. metodę fosforanową. Polega ona na analizie zawartości fosforu w glebie. Jego zwiększona ilość może świadczyć o nasilonym rozkładzie materii organicznych - sytuacja, z którą możemy mieć do czynienia w przypadku jamy grobowej. Badaniom poddaje się próbki ziemi o masie około $1 \mathrm{~g}$ pobrane z głębokości 10-20 cm w odpowiednich odstępach. Analizę przeprowadza się przy pomocy odczynników barwiących - im bardziej intensywny kolor uzyskamy, tym większa będzie zawartość fosforu w próbce (Lawecka 2010: 74-75). Typową i powszechnie stosowaną $\mathrm{w}$ archeologii metodą badań inwazyjnych są wykopy sondażowe. Przybierają one postać rowów lub niewielkich, regularnych wykopów przecinających stanowisko archeologiczne w różnych miejscach. Mogą one być, w zależności od sytuacji, wykonywane ręcznie lub przy użyciu koparki. Sondaże tego typu pozwalają zazwyczaj na potwierdzenie wyników badań nieinwazyjnych oraz gdy jest to konieczne - zaplanowanie wykopalisk szerokopłaszczyznowych. Te drugie znajdują zastosowanie raczej w archeologii. Natomiast sondaże są konieczne do potwierdzenia wyników otrzymanych $\mathrm{z}$ badań georadarem lub też przy użyciu metod chemicznych. Policyjne ekipy dochodzeniowe nie raz skutecznie korzystały już z podobnych środków w celu odnalezienia zwłok (Stojer-Polańska i in. 2015: 4-6).

Archeolodzy podczas swoich badań badają warstwy kulturowe o zróżnicowanej chronologii. Bardzo duże znaczenie ma w tym przypadku stratygra- 
fia i kontekst w jakim znajdowane są wszelkiego rodzaju przedmioty. Dopiero dokładna analiza tych wszystkich czynników pozwala na opracowanie teorii dotyczącej konkretnego miejsca lub wydarzenia. W przypadku prowadzenia czynności postępowania przygotowawczego chodzi najczęściej o pojedyncze zdarzenie o gwałtownym przebiegu (Kawecki i in. 2013: 150-151). Dlatego też pewne elementy mają dla kryminalistyków mniejsze znaczenie niż dla archeologów. W przypadku dochodzenia prokuratorskiego w Charkowie i Miednoje w 1991 r. ekipa badawcza musiała dostosować się do narzuconych ograniczeń czasowych i zastosować uproszczone metody eksploracji - bez uwzględniania szczegółowej stratygrafii, użycia specjalistycznej aparatury pomiarowej w celu trójwymiarowej lokalizacji eksplorowanych obiektów oraz sporządzanej na bieżąco dokumentacji graficznej. Niemniej jednak podjęte działania okazały się całkowicie wystarczające na potrzeby dochodzenia i umożliwiły zrealizowanie wszystkich celów (Nadolski, Głosek 1992: 248-249).

\section{EKSPLORACJA MOGILY}

Prace związane z eksploracją mogiły należy rozpocząć od przygotowania technicznego i odpowiedniej organizacji. Dokładne rozplanowanie wszystkich działań ma szczególne znaczenie w przypadku terenowego dochodzenia, które w przeciwieństwie do badań archeologicznych jest obwarowane ścisłymi procedurami postępowania. Zespół dochodzeniowy składa się często z przedstawicieli różnych nauk (archeologów, antropologów, lekarzy medycyny sądowej), dlatego istotne jest właściwe skoordynowanie ich działań. $\mathrm{Z}$ tego też powodu organizuje się odprawy, na których informuje się uczestników prac o przyjętych metodach postępowania, harmonogramie czasowym, a także dokonuje się podziału obowiązków. Wszystkimi działaniami w terenie kieruje jedna osoba, stale obecna na miejscu i podejmująca decyzje na bieżąco, zgodnie z postępem badań. Przygotowanie techniczne to zgromadzenie odpowiedniego sprzętu niezbędnego w terenie. Są to przede wszystkim podstawowe narzędzia: łopaty, szpadle, siekiery, kilofy, łopatki ogrodnicze, szpachelki. Do tego dochodzą kołki, szpile, miarki i taśmy do wymierzania wykopów oraz potrzebne bezpośrednio przy zwłokach pędzelki i szczotki różnego rodzaju. Dokumentację wykonuje się przy użyciu aparatu fotograficznego oraz sprzętu do rysowania: rysownica, ołówki, linijki, papier milimetrowy (Kawecki i in. 2013: 159-160). Poza tym jest jeszcze specjalistyczny sprzęt geodezyjny: magnetometry, georadary, a także niwelatory i teodolity do wykonywania pomiarów. Metody geodezyjne zostały już omówione w poprzednim podrozdziale.

Po odpowiednim przygotowaniu można podjąć prace bezpośrednio przy mogile. Po natrafieniu na ślady wskazujące możliwą obecność szczątków 
kostnych w obrębie wykopu należy przede wszystkim określić wielkość jamy grobowej. Po odsłonięciu jej zarysu przystępuje się do usunięcia zasypiska. Eksplorację wnętrza mogiły można prowadzić na dwa sposoby. Jeden z nich to metoda stratygraficzna (usuwanie kolejnych warstw w obrębie jamy) połączona z obserwacją wzajemnych zależności między grobem, a jego otoczeniem. Inny sposób to tzw. metoda „katafalku” polegająca na usuwaniu ziemi tylko wokół szkieletu, tak aby szczątki pozostały na podwyższeniu i był do nich łatwy dostęp. Układ, w jakim znajdują się kości może być naprawdę zróżnicowany, dlatego do każdej mogiły należy podchodzić indywidualnie. Szkielet może być z różnych powodów zdekompletowany (np. poprzez działalność zwierząt ryjących w ziemi), często w przypadku grobów masowych ofiar zbrodni ludobójstwa zwłoki mogą być ze sobą bardzo przemieszane. Eksplorację zaczyna się od najwyżej położonych części szkieletu stopniowo kierując się coraz niżej. Ziemię usuwa się drobniejszymi narzędziami takimi jak łopatki ogrodnicze lub szpachelki, aby jak najlepiej odsłonić układ szkieletów. Kości oczyszcza się delikatnie przy pomocy pędzelków i szczoteczek. Poruszając się w obrębie grobu należy zachować szczególną ostrożność, tak aby nie uszkodzić szczątków ani zalegających przy nich przedmiotów. Po odsłonięciu zwłok podlegają one zmianie temperatury i wilgotności otoczenia, co może mieć niekorzystny wpływ na zachowanie się materiału kostnego. Szczątki nie powinny być zbyt długo odsłonięte, w razie potrzeby pozostawienia ich na kilka godzin w stanie nienaruszonym, można je przykryć folią. Po odsłonięciu zwłok, należy przystąpić do stworzenia dokumentacji wnętrza grobu z uwzględnieniem układu, w jakim znajdują się kości oraz położenia całego materiału zabytkowego wokół. Dopiero potem można przystąpić do podjęcia szczątków z miejsca spoczynku. Należy to robić delikatnie, odsłaniając najpierw w całości kość, którą chcemy wyciągnąć, tak aby nie była mocno związana z podłożem. Dobrze jest zacząć od kończyn dolnych. Jeśli kości stopy znajdują się w butach, nie należy ich wyciągać, trzeba je spakować do osobnych worków. Jeśli spoczywają luzem - podobnie, pakuje się je do oddzielnych worków strunowych i załącza stosowny opis. Następnie podejmuje się pozostałe kości kończyn dolnych, miedniczne, kość krzyżową i odcinek lędźwiowy kręgosłupa. W przypadku kończyn górnych, postępuje się podobnie jak przy dolnych. Dalej należy wyciągnąć mostek, żebra, obojczyki, kręgi piersiowe i szyjne oraz łopatki. Na samym końcu podejmuje się czaszkę z żuchwą. Na bieżąco wyciąga się również materiał zabytkowy, umieszczając przedmioty w woreczkach strunowych i opisując. Szczątki kostne najlepiej jest złożyć do kartonowych pudełek. Taki model postępowania jest oczywiście możliwy gdy ekshumujemy zeszkieletowane zwłoki. Niekiedy jednak zachowane są tkanki miękkie, zwłoki mogą być w trakcie przemiany thuszczowo-woskowej. Nie należy ich wtedy rozdzielać, na- 
tomiast do ich transportu może posłużyć wtedy worek na zwłoki. Szczątki zmumifikowane są z kolei bardzo kruche najlepiej więc umieścić je w całości w sztywnym opakowaniu o właściwym rozmiarze, np. w trumnie kartonowej. Po zakończeniu ekshumacji trzeba dokładnie sprawdzić jamę grobową, czy nie pozostały tam jeszcze jakieś szczątki kostne lub przedmioty. Należy podczyścić dno wykopu oraz profile w celu upewnienia się, że obok albo poniżej nie znajduje się kolejna mogiła. Po zakończeniu prac konieczne jest przywrócenie terenu do stanu sprzed rozpoczęcia badań, czyli zasypanie wykopów. Jeśli podczas tej czynności zostaną znalezione jeszcze jakieś przedmioty, w przypadku badań archeologicznych zostają często dołączone do inwentarza, jednak przy czynnościach procesowych zakopuje się je z powrotem jeśli nie były wcześniej włączone do materiału dowodowego (Kawecki i in. 2013: 160-165).

W przypadku grobów zawierających szczątki więcej niż jednej osoby rozróżniamy groby masowe i zbiorowe. Grób masowy to taki, w którym znajdują się ciała lub szczątki co najmniej dwóch osób, złożone w tym samym czasie i mające ze sobą styczność. Mogiła zbiorowa natomiast charakteryzuje się tym, że kolejne ciała były składane w odstępie czasowym, po ponownym otwarciu grobu (np. groby rodzinne). Różnica polega również na tym, że powstanie mogiły zbiorowej wynika z przyjętych zwyczajów pogrzebowych, natomiast grób masowy świadczy o jednoczesnej i nagłej śmierci pewnej grupy osób, co często wiąże się ze złamaniem prawa i wymaga przeprowadzenia czynności śledczych. Postępowanie w obu przypadkach jest właściwie bardzo podobne, jak przy ekshumacji pojedynczych pochówków, należy jednak liczyć się z tym, że pewne problemy napotkamy w większej skali - mogą zaistnieć trudności choćby przy dokumentacji i wiernym oddaniu układu szczątków lub przy kompletowaniu poszczególnych szkieletów (Kawecki i in. 2013: 166-167).

Szczątki kostne pochodzące $\mathrm{z}$ grobu masowego mogą być potraktowane dwojako. Powszechnie przyjętą przez medyków sądowych metodą jest ekshumowanie wszystkich szkieletów z grobu, a następnie uporządkowanie kości według ich rodzajów (czaszki jako osobna grupa, piszczele jako inna itd.). Później są one zliczane i na tej podstawie szacowana jest liczba ciał jaka znajdowała się w obrębie grobu. Takie postępowanie przyjęto m.in. w czasie trwania dochodzenia w Charkowie i Miednoje w 1991 r., został on następnie zaadaptowany podczas późniejszych badań archeologicznych miejsc ukrycia ofiar Starobielska prowadzonych przez Andrzeja Kolę z toruńskiego ośrodka archeologicznego. Inną metodą jest podejmowanie zwłok w porządku anatomicznym, tak aby każdy oddzielny szkielet zachowany był w miarę możliwości w komplecie. Marian Głosek kierujący pracami ekshumacyjnymi w Katyniu nie zgodził się na zastosowanie wyżej opisanej metody medyków sądowych i postanowił oprzeć się 
na własnych doświadczeniach z badań archeologicznych. Ten sposób został powszechnie przyjęty w badaniach prowadzonych z udziałem łódzkiego ośrodka archeologicznego ${ }^{1}$.

\section{IDENTYFIKACJA ZWŁOK I SZCZĄTKÓW LUDZKICH}

W antropologii, medycynie sądowej i kryminalistyce stosuje się szereg metod, na podstawie których możliwe jest ustalenie tożsamości zwłok lub szczątków ludzkich. Dobór odpowiedniej metody należy do osoby prowadzącej badania lub oględziny. Na podjęcie tej decyzji ma wpływ stan, w jakim zostały znalezione szczątki. Pod tymi względami praca archeologów i kryminalistyków wygląda dość podobnie, a przy ostatecznej identyfikacji zwłok korzysta się najczęściej z usług antropologa lub lekarza medycyny sądowej.

Analizuje się przede wszystkim cechy odzieży, obuwia oraz przedmiotów, które mogły zostać znalezione wewnątrz mogiły. Wszystkie te rzeczy należy odpowiednio zabezpieczyć do dalszych badań przy których zwraca się uwagę m.in. na rozmiar, fason, model, ewentualne naprawy lub modyfikacje odzieży. Znaki szczególne występujące na ciele lub indywidualne parametry antropologiczne szczątków kostnych to kolejna kategoria, na którą należy zwrócić uwagęe Do znaków szczególnych zalicza się tatuaże, wszelkiego rodzaju blizny, amputacje, uzupełnienia ciała wykonane ze sztucznych materiałów (protezy, metalowe łączniki ortopedyczne). Zmiany kostne to np. wyjątkowo niski lub wysoki wzrost, wady postawy lub kończyn. Najskuteczniejszą metodą ustalenia tożsamości jest przeprowadzenie badań DNA ale w tym przypadku konieczne jest dysponowanie materiałem porównawczym. Analizuje się także stan uzębienia, co w przypadku archeologii może zasugerować wiek osoby oraz przynależność do klasy społecznej, a przy współczesnych działaniach kryminalistycznych pozwala ponadto na identyfikację ofiary (Kowal 2009: 109-111).

Dokładne badania szkieletów ludzkich mogą dostarczyć informacji dotyczących wzrostu, wieku oraz płci osoby pochowanej. Odbywa się to m.in. poprzez dokonanie pomiarów kości kończyn długich i kręgosłupa, jak również analizę cech morfologicznych czaszki i miednicy. Możliwe jest np. określenie wieku poprzez badania stopnia zrośnięcia szwów czaszkowych. Wykonanie takiej oceny bez długotrwałej obróbki pobranego materiału obarczone jest jednak pewnym niewielkim błędem. Nie ma to większego znaczenia w przypadku badań archeologicznych czy antropologicznych, ale nie zawsze sprawdza się przy identyfikacji zwłok na potrzeby postępowania karnego (Bednarek i in. 2005: 185-189).

Dobrym sposobem identyfikacji szczątków jest również metoda superprojekcji. Potrzebne jest do tego jednak zdjęcie ofiary/osoby zaginionej. Przy pomocy

\footnotetext{
${ }^{1}$ Informacja uzyskana od prof. dr hab. Mariana Głoska.
} 
technik komputerowych, dokonuje się zestawienia wizerunku twarzy z czaszką i na podstawie cech morfologicznych następuje określenie zgodności (Kowal 2009: 112-113).

Rekonstrukcja plastyczna to metoda kryminalistyczna polegająca na odtwarzaniu części kostnych czaszek i tkanek miękkich głów w celach identyfikacyjnych. Wykonuje się to tzw. techniką Gierasimowa - od nazwiska rosyjskiego antropologa i archeologa, który określił średnie wartości grubości tkanek w poszczególnych częściach głowy dla konkretnych typów antropologicznych. Wartości te zostały przyjęte jako podstawowe standardy i są wykorzystywane współcześnie. Dawniej twarz rekonstruowano poprzez nakładanie na odlew czaszki warstw plastycznego materiału, a następnie modelowanie go przez rzeźbiarza współdziałającego z antropologiem. Obecnie bardziej popularne są specjalistyczne oprogramowanie i techniki komputerowe, niemniej jednak stosuje się dokładnie te same zasady i wartości co przy dawniejszych metodach (Kempińska-Podhorecka i in. 2007: 114-115).

Pewne zastosowanie w kryminalistyce może również znaleźć popularne $\mathrm{W}$ archeologii datowanie przy użyciu izotopu węgla ${ }^{14} \mathrm{C}$. Na skutek powstania broni jądrowej i związanych z tym próbnych wybuchów wprowadzone zostały do atmosfery duże ilości ${ }^{14} \mathrm{C}$. Takie zaburzenie środowiska umożliwiło zwiększenie dokładności wyników w stosunku do próbek pochodzących z drugiej połowy XX w. Daje to możliwość potwierdzenia lub wykluczenia przypuszczalnej daty śmierci (Walanus 2010: 69-70).

\section{DOKUMENTACJa}

Podstawowe formy dokumentacji stosowane w archeologii oraz w kryminalistyce to opisowa, rysunkowa i fotograficzna. Pierwsza z nich, w przypadku stanowiska archeologicznego, przybierze postać dziennika badań oraz wszelkiego rodzaju inwentarzy. Funkcję dzienników mogą pełnić zwyczajne notatniki polowe lub wcześniej przygotowane karty opisowe z odpowiednimi rubrykami. Powinny one zawierać wszystkie informacje (hipotezy, opisy, uwagi, wyniki pomiarów, rysunki) dotyczące dziennego przebiegu pracy, zwłaszcza te, które nie będą zapisane w innej formie. Stosuje się także karty opisu warstw stratygraficznych i odkrytych obiektów. Inwentarze można podzielić na dwie kategorie. Pierwsza, to spisy dotyczące wszystkiego, co zostało odkryte na badanym stanowisku - obiektów, zabytków, próbek, jednostek stratygraficznych. Druga kategoria jest natomiast wyszczególnieniem pozostałej dokumentacji dotyczącej prowadzonych prac - rysunków i fotografii (Ławecka 2010: 125-132).

W przypadku badań kryminalistycznych podstawą jest sporządzenie protokołu oględzin miejsca zdarzenia. Należy to do obowiązków osoby odpowie- 
dzialnej za przeprowadzenie czynności na miejscu, protokół taki sporządza się w ścisłej współpracy z technikiem kryminalistyki. Podstawowe elementy zawarte $w$ takiej dokumentacji to przede wszystkim rodzaje ujawnionych śladów wraz z ich lokalizacją, cechy charakterystyczne znalezionych przedmiotów, metody zastosowane do ich wykrycia oraz zabezpieczenia, przyporządkowane im numery i różne informacje (np. czy przedmiot został sfotografowany). Protokół powinien też trzymać się kilku podstawowych zasad takich jak dokładność, bezpośredniość, obiektywizm, komunikatywność, zwięzłość opisu, jednolita nomenklatura, czy zastosowanie bezosobowej formy gramatycznej (Mazepa 2009: 45-51). Protokół oględzin można tak naprawdę przyrównać do archeologicznego dziennika badań. Przy tworzeniu opisów powinno się używać jak najmniej pojęć specjalistycznych zastępując je zwrotami powszechnie stosowanymi. Do innych rodzajów dokumentacji kryminalistycznej należy również zaliczyć opinie biegłych (np. archeologa obecnego przy ekshumacji lub lekarza medycyny sądowej badającego odkryte szczątki), notatki sporządzane na bieżąco oraz inwentarze, które, tak jak w archeologii, tworzy się dla odnalezionego materiału dowodowego oraz dla pozostałej dokumentacji rysunkowej i fotograficznej. W przypadku badań grobu można także zastosować tzw. kartę pochówku zawierającą informacje takie jak numer inwentarzowy pochówku, czas i miejsce prowadzenia badań, określenie pozycji stratygraficznej względem otoczenia, wielkość jamy grobowej i jej zasypiska, układ i stan zachowania szczątków, wykaz przedmiotów znalezionych $\mathrm{w}$ mogile oraz sporządzonej dokumentacji. Karta taka może być elementem protokołu lub oddzielnym załącznikiem (Kawecki $i$ in. 2013: 171-173).

Dokumentacja rysunkowa na stanowisku archeologicznym to przede wszystkim plany poszczególnych warstw i obiektów, zabytków ruchomych w miejscu ich znalezienia oraz przekroje. Plany wykonuje się głównie przy pomocy siatki metrowej zorientowanej poziomo, a w przypadku warstw stratygraficznych - pionowo. Wszystkie wykonane rysunki powinny zawierać zestaw podstawowych informacji. Należą do nich: tytuł i krótki opis, numer inwentarzowy, skala, orientacja według stron świata, szczegółowa lokalizacja, data i podpis autora. Skalę dobiera się w zależności od tego, co w danej chwili podlega dokumentacji. Skala rzędu 1:1000 może być zastosowana do sporządzenia planu lokalizacyjnego miejsca prowadzonych badań, z kolei 1:100 lub 1:50 - w przypadku szczegółowego planu. Poszczególne elementy na stanowisku, czyli groby, obiekty, przekroje warstw często dokumentuje się w skali 1:20, nie zawsze jednak wystarczy ona do oddania wszystkich detali, dlatego czasem rysuje się nawet $\mathrm{w}$ proporcji 1:1. Przy ekshumacji można ją zastosować do narysowania szczegółów anatomicznego układu szczątków kostnych, a także zaobserwowanych na nich obrażeń. Dokumentację rysunkową sporządza się ołówkiem (Ławecka 2010: 122-123; Kawecki i in. 2013: 173). 
W praktyce kryminalistycznej istnieją dwa rodzaje rysunków - szkice i plany. Szkic miejsca zdarzenia wykonuje się na bieżąco w czasie trwania oględzin $\mathrm{w}$ formie odręcznego rysunku przedstawiającego samo miejsce oraz odkryte na nim ślady i przedmioty o znaczeniu dowodowym dla sprawy. Można go sporządzić na dowolnym podłożu, nie musi on być wyskalowany, ale powinien zachowywać proporcje i mieć naniesione wymiary. Należy go zorientować według stron świata, zaopatrzyć w umowne znaki topograficzne i kryminalistyczne oraz opisy dotyczące zdarzenia wraz z zapiskami pomocniczymi. W przeciwieństwie do archeologii niedopuszczalne jest rysowanie ołówkiem. Jego wykonanie nie jest również obowiązkowe, decyzję taką podejmuje prowadzący oględziny w zależności od sytuacji (np. przy braku możliwości sporząazenia przejrzystego opisu sytuacji w protokole). Muszą go ponadto podpisać wszystkie osoby biorące udział w czynnościach. Plan miejsca zdarzenia wykonuje się już po zakończeniu działań w terenie na podstawie sporządzonego wcześniej szkicu. Wykorzystuje się do tego celu przybory kreślarskie oraz papier milimetrowy lub kalkę techniczną. Obecnie dopuszczalne jest także wykonywanie go przy użyciu programów komputerowych. Plan musi być wyskalowany, opisany legendą $\mathrm{i}$ zorientowany $\mathrm{w}$ terenie zgodnie $\mathrm{z}$ kryminalistycznymi zasadami. Podobnie, jak na szkicu nanosi się na niego umowne znaki topograficzne i kryminalistyczne. Na planie wymagany jest podpis tylko jego autora (Mazepa 2009: 51-53).

W czasie archeologicznych prac wykopaliskowych na każdym etapie fotografuje się ogólną powierzchnię badanego stanowiska, odkryte obiekty, przekroje, materiał zabytkowy w miejscu jego znalezienia oraz już po wydobyciu. Obecnie do sporządzania takiej dokumentacji wykorzystuje się najczęściej aparaty cyfrowe. Duża ilość funkcji i trybów pracy takiego aparatu pozwala na sfotografowanie tego samego przedmiotu na różne sposoby, zdjęcia od razu są zapisywane w postaci komputerowych plików graficznych, co ułatwia poddanie ich dalszej obróbce z użyciem odpowiedniego programu. Wykonanie dobrej fotografii wymaga oczywiście pewnego przygotowania. Należy przede wszystkim dokładnie oczyścić fotografowany obszar, tak aby uwidocznić najistotniejsze elementy, na zadokumentowaniu których nam zależy. Trzeba zwrócić uwagę na oświetlenie - wiąże się to z doborem odpowiedniej pory dnia lub użyciem sprzętu takiego jak ekrany zaciemniające lub lampy błyskowe. Nie powinno się robić zdjęć w silnym ostrym świetle ani też fotografować obiektów częściowo zacienionych. W celu uniknięcia zniekształceń obrazu, zdjęcia robi się z pewnej wysokości i w miarę możliwości pionowo. Dokumentowane obiekty i przedmioty powinny być opatrzone skalą i oznaczeniem północy w postaci strzałki. Czasem wymagana jest również tablica $\mathrm{z}$ opisem zawierającym datę wykonania zdjęcia, miejscowość, szczegółową lokalizację fotografowanego obiektu i numer inwentarzowy zdjęcia (Ławecka 2010: 132-133; Kawecki $\mathrm{i}$ in. 2013: 174-175). 
Sporządzanie dokumentacji fotograficznej jest nieco bardziej skomplikowane w odniesieniu do fotografii kryminalistycznej. Stanowi ona odrębny dział kryminalistyki. Wyróżnia się m.in. specyfiką dokumentowanych obiektów, odpowiednio wypracowanymi metodami i sposobami robienia zdjęć oraz ściśle określonymi zasadami narzuconymi przez prawo i technikę kryminalistyczną. Istnieje tu także podział na cztery kategorie (Mazepa 2009: 80-83):

- Fotografia rejestracyjna - zajmuje się rejestrowaniem osób (fotografia sygnalityczna) i rzeczy na potrzeby kartotek i zbiorów. Zdjęcia takie wykonuje się osobom podejrzanym o popełnienie przestępstwa ściganego z oskarżenia publicznego, nieletnim dopuszczającym się czynów zabronionych oraz osobom o nieustalonej tożsamości. W przypadku gdy nie ma możliwości zidentyfikowania zwłok, wykonuje się również fotografię sygnalityczną (Dz.U. KGP Nr 9, poz. 47).

- Fotografia dokumentacyjna - najdokładniejsze z możliwych odwzorowanie przedmiotów i zjawisk dostrzegalnych wzrokowo.

- Fotografia badawcza - rodzaj fotografii pozwalającej m.in. na uchwycenie śladów, zjawisk i cech obiektów niedostatecznie lub całkowicie niewidocznych wzrokowo (np. wygląd i stan poruszających się z dużą prędkością przedmiotów).

- Fotografia detektywna - zdjęcia pochodzące z obserwacji osób lub miejsc powiązanych z działalnością przestępczą. Celem jest wykonanie fotografii w sposób na tyle dyskretny, aby móc zarejestrować swobodne zachowanie osób przed, w trakcie i po dokonaniu czynu.

Szczegóły dotyczące metod i sposobów wykonywania fotografii kryminalistycznej można znaleźć w literaturze specjalistycznej poświęconej tym zagadnieniom (np. Mazepa 2009: 79-130).

\section{PrzYKŁAdY WSPÓ PRACY ARCHEOLOGów I KRYMINALISTYKóW PRZY EKSPLORACJI MOGIL}

W 1960 r. podjęte zostało, przez Okręgową Komisję Badań Zbrodni Hitlerowskich w Zielonej Górze, śledztwo w sprawie zbrodni popełnionych przez Wehrmacht w obozach Stalag VIII C w Żaganiu i Stalag 308/VIII E w Świętoszowie. W latach 1960-1961 przeprowadzano na ich terenach czynności ekshumacyjne i sądowo-lekarskie oględziny zwłok. Mało precyzyjne wyniki poskutkowały wznowieniem dochodzenia w 1972 r. Zeznania świadków dotyczące lokalizacji grobów okazały się bezużyteczne (zarówno relacje naocznych świadków z okresu wojny, jak i funkcjonariuszy wykonujących ekshumacje w latach 60.). W przybliżeniu określono tylko kompleks leśny, który stał się obiektem badań. W celu zlokalizowania mogił podjęto współpracę z archeologami z Muzeum Okręgowego w Zielonej Górze - Adamem Kołodziejskim i Andrzejem 
Marcinkianem. Zdecydowano się na zastosowanie systemu wykopów sondażowych. Odkryto trzy groby masowe, w których zwłoki oczyszczono i poddano oględzinom sądowo-lekarskim oraz badaniom archeologicznym. Przy niektórych szkieletach natrafiono na jenieckie tabliczki ewidencyjne, pozwalające na identyfikację. Na podstawie stratygrafii ustalono łączną ilość mogił na terenie lasu na 61, a w oparciu o dane z ekshumacji 3 grobów oszacowano liczbę zwłok na 5978. Wykonano także wykop sondażowy w innej części terenu, gdzie natrafiono na ślady cmentarzyska mogił pojedynczych. Archeolodzy sporządzili dokumentację ze swoich badań, która została włączona do akt śledztwa. Postawione przed zespołem cele zostały w pełni zrealizowane, a uzyskane wyniki potwierdziły przydatność stosowania metod archeologicznych przy lokalizacji mogił masowych (Sojka 1977: 211-232).

Kilka razy zostało przytoczone w tekście terenowe dochodzenie prokuratorskie mające miejsce w 1991 r. w Charkowie i Miednoje. W ekipie kierowanej przez prokuratora Stefana Śnieżkę dominowali funkcjonariusze policji, technicy kryminalistyki i przedstawiciele prokuratury. Zdecydowano się jednak włączyć również w skład ekipy archeologa - Andrzeja Nadolskiego, pracownika naukowego z dużym doświadczeniem w zakresie badania pól bitewnych i historii wojskowości. W czasie prac ekshumacyjnych w Miednoje został on zastąpiony przez M. Głoska. Na obu stanowiskach prace prowadzone były przy użyciu koparki, a po natknięciu się na mogiłę eksplorację kontynuowali żołnierze radzieccy. Po wyciągnięciu szczątków z jamy grobowej, były one badane przez lekarzy medycyny sądowej, falerystę - mundurologa oraz dokumentalistów. Strona radziecka i strona polska sporządzały oddzielne raporty z przebiegu prac, które okazały się jednak zbyt mało dokładne, aby umożliwić weryfikację wyników badań w latach późniejszych. Archeolog nie miał decydującego zdania w doborze metod badawczych, specjalistycznego sprzętu i sporządzania dokumentacji. Z braku czasu przyjęto uproszczoną metodę eksploracji, pomijającą zasady wykorzystywane powszechnie w archeologii (m.in. uwzględnienie pełnej stratygrafii obiektów i ich trójwymiarową lokalizację), jednak na potrzeby prowadzonego dochodzenia zastosowane sposoby okazały się wystarczające i pozwoliły zrealizować wyznaczone cele (Nadolski, Głosek 1992: 248-263; Głosek 1996: 259-266).

Na skutek dochodzenia prokuratorskiego, w 1994 r. przeprowadzono pierwsze poszukiwania miejsca ukrycia zwłok kapitana Stanisława Sojczyńskiego ps. „Warszyc” - dowódcy Konspiracyjnego Wojska Polskiego, rozstrzelanego 17 lutego 1947 r. wraz z 5 ludźmi przez pracowników Urzędu Bezpieczeństwa na terenie poligonu wojskowego Brus w Łodzi. Poszukiwania miały formę badań archeologicznych metodą wykopów sondażowych w miejscu wskazanym przez byłego prokuratora Henryka Szweda, który po egzekucji potwierdził tożsamość zabitego. Nie odnotowano jednak pozytywnych wyników. Dalsze dzia- 
łania podjęto dopiero 16 maja 1997 r. Na polecenie prokuratora Arkadiusza Dynowskiego na Brusie pojawiła się ekipa archeologów i studentów archeologii UŁ kierowana przez M. Głoska z Zakładu Archeologii i Etnologii PAN w Łodzi. Wykorzystując doświadczenia z poszukiwań cmentarzy polskich oficerów na Wschodzie, dokonano odwiertów świdrem geologicznym. Nie natrafiono jednak na żadne ślady mogące świadczyć o obecności mogiły masowej. Badania były kontynuowane w latach późniejszych (Muzolf, Góra 1997: 159-161).

W 1967 r. rozpoczęła się współpraca jaką podjął Zakład Archeologii Śródziemnomorskiej PAN z Zakładem Kryminalistyki Komendy Głównej Milicji Obywatelskiej. Archeolodzy zwrócili się wówczas z prośbą do kryminalistyków o przeprowadzenie badań materiałów z okolic Aleksandrii za pomocą aparatury rentgenowskiej. Jednym z ciekawszych projektów obu instytucji było badanie dermatoglifów (ogólnego obrazu układu linii papilarnych ręki lub stopy) mumii, którego na zlecenie Zakładu Archeologii Sródziemnomorskiej PAN podjęli się Tadeusz Dzierżykray-Rogalski, Elżbieta Promińska i Czesław Grzeszyk. W 1974 r. pobrano odciski linii papilarnych z mumii faraońskich w Muzeum Egipskim w Kairze - Ramzesa II, Seti II, Siptaha i Nedjemet. Pozyskany materiał nie był kompletny ponieważ pochodził tylko z części dłoni i stóp niezakrytych bandażami. Analizie poddano układy listewek skórnych, ich budowę i częstość występowania konkretnych typów cech. Porównano je z wzorami na dłoniach i stopach ludzi współczesnych. Pod względem układów listewek skórnych nie zanotowano znaczących różnic, natomiast mumie egipskie charakteryzowały się niewielką ilością poszczególnych typów cech (oczek, mostków haczyków i złączeń) z ograniczeniem do podstawowych form. Otwarta pozostała kwestia zmian mikroewolucyjnych linii papilarnych - mogło być to spowodowane małżeństwami zawieranymi przez spokrewnionych członków rodów lub też genetycznym przystosowaniem wynikającym z braku potrzeby pracy fizycznej i zanikiem pewnych cech związanych ze współczynnikiem tarcia (Baran i in. 1976: 268-280). Co ciekawe, eksperyment ten został najprawdopodobniej zapomniany gdyż w publikacji kryminalistycznej opisany jest przykład podobnego, niedawno wykonanego doświadczenia - daktyloskopowania mumii ze zbiorów Muzeum Anatomii Prawidłowej i Klinicznej Warszawskiego Uniwersytetu Medycznego. Celem było sprawdzenie czy da się pobrać ślady daktyloskopijne i wypracowanie optymalnych metod. Ustalono, że możliwe jest pozyskanie materiału umożliwiającego teoretycznie identyfikację. Autorzy artykułu zaznaczyli też, że eksperyment miał jednostkowy charakter i nie są im znane wyniki podobnych doświadczeń (Mańkowska-Pliszka i in. 2016: 30-34).

Przykładem zastosowania metod kryminalistycznych na potrzeby archeologii były badania Muzeum Archeologicznego w Gdańsku. Podczas prac prowadzonych na terenie Starego Miasta, natrafiono na ludzkie szczątki, które wydatowano na przełom XII i XIII w. Na podstawie ośmiu znalezionych czaszek 
postanowiono dokonać rekonstrukcji plastycznej twarzy metodą Gierasimowa. Zadania podjął się Zakład Medycyny Sądowej Pomorskiej Akademii Nauk. Praca tego rodzaju uwzględnia pewne ustalone wartości charakterystyczne dla cech morfologicznych danego typu antropologicznego, jednak jest ona obarczona subiektywizmem autora - nadania twarzy pewnych cech cery lub mimiki, które nie są możliwe do potwierdzenia. W niektórych publikacjach dominuje pogląd, że metoda ta nie jest wystarczająco wiarygodna i dokładna, aby móc z niej korzystać w postępowaniu dowodowym. Stwierdzono jednak, że antropologia historyczna nie ma tak rygorystycznych wymagań jak kryminalistyka i kładzie nacisk na odtworzenie ogólnego wyglądu ludzi żyjących w minionych epokach, gdzie cechy indywidualne nie mają zbyt dużego znaczenia. Przyjmując takie założenie, można z powodzeniem stosować tę metodę do celów archeologicznych i antropologicznych (Kempińska-Podhorecka i in. 2007: 113-121).

\section{WNIOSKI KOŃCOWE}

Z przyczyn metodologicznych zagadnienie eksploracji mogił zostało przedstawione przede wszystkim z perspektywy archeologicznej. Mimo to, podobny sposób postępowania $w$ tych przypadkach dotyczyłby również techników kryminalistyki. Literatura poświęcona tej drugiej dziedzinie nie precyzuje jednak metod postępowania w specyficznych przypadkach - podaje raczej ogólne wytyczne co do procedur podejmowanych na miejscu zdarzenia. Kryminalistyka, poza własnymi technikami, w bardzo dużej mierze czerpie z osiągnięć medycyny sądowej, antropologii i archeologii czego dobrym przykładem jest $\mathrm{np}$. ograniczone wykorzystanie metody datowania izotopu węgla ${ }^{14} \mathrm{C}$ na potrzeby dochodzeniowe. Istotną różnicą jest również fakt, że archeolodzy w terenie pracują na ogół samodzielnie i muszą posiadać aktualną wiedzę na temat najbardziej optymalnych metod badawczych, zaś w skład zespołów dochodzeniowo-śledczych przeważnie wchodzą biegli, którzy mogą zasugerować wykorzystanie znanych im środków i technik, które w najłatwiejszy sposób poprowadzą do osiągnięcia celu.

Różnice, jakie dzielą archeologów i techników kryminalistyki widoczne są przede wszystkim $\mathrm{w}$ procedurach i ograniczeniach prawnych, a także $\mathrm{w}$ fachowym języku używanym przez jednych i drugich specjalistów. Największe rozbieżności można dostrzec w przypadku dokumentacji badań. Podstawowe kategorie sporządzanych dokumentów są podobne - opisowe, rysunkowe i fotograficzne. Niekiedy spełniają właściwie taką samą funkcję, tak jak sprawozdanie z badań archeologicznych i protokół z przeprowadzenia oględzin miejsca zdarzenia, różnią się jednak nazewnictwem. W przypadku dokumentacji graficznej, archeolog dysponuje szerszym zakresem rysunków, jakie musi lub 
może wykonać - są to szkice, plany stanowiska archeologicznego, dokładna dokumentacja jamy grobowej, szkieletu wraz z materiałem zabytkowym, a także profile wykopu dla uchwycenia stratygrafii. Kryminalistyka ogranicza się właściwie do szkiców i planów kryminalistycznych miejsca zdarzenia, przy czym jest dokładnie określone kto, w jaki sposób i w jakich okolicznościach powinien wykonać tego rodzaju dokumentację. Oprócz tego jednak, powstaje jeszcze oddzielna dokumentacja sporządzana przez biegłych obecnych na miejscu zdarzenia zgodnie z zasadami jakie wynikają z ich doświadczeń. Kryminalistyka ma jednak, w przeciwieństwie do archeologii, dużo bardziej rozwinięty dział fotografii, który stał się tam właściwie odrębną specjalizacją. Istnieje podział na kilka różnych kategorii oraz dokładne wytyczne, w jaki sposób robić odpowiednie zdjęcia znajdujące zastosowanie $\mathrm{w}$ tej pracy.

Podejmowanie współpracy przez specjalistów z obu dziedzin jest dobrą drogą rozwoju tych nauk czego przykładem może być wyodrębnienie się tzw. archeologii sądowej.

Adam Górecki

Doktorant w Instytucie Archeologii Uniwersytetu Łódzkiego

ul. Narutowicza 65

90-131 Łódź

e-mail: adam.gorecki@yandex.ru

\section{Bibliografia}

\section{Źródla}

Rozporządzenie Ministra Zdrowia z dnia 7 grudnia 2001 r. w sprawie postępowania ze zwtokami i szczatkami ludzkimi (Dz.U. $2001 \mathrm{Nr}$ 153, poz. 1783).

Ustawa z dnia 6 czerwca 1997 r. kodeks karny (Dz.U. 2017, poz. 2204).

Ustawa z dnia 6 czerwca 1997 r. kodeks postepowania karnego (Dz.U. 2017, poz. 1904). Zarządzenie Komendanta Głównego Policji nr 64 z dnia 17 marca 2003 r. zmieniające zarzadzenie $w$ sprawie uzyskiwania, przetwarzania $i$ wykorzystywania przez Policję informacji oraz sposobów zakładania i prowadzenia zbiorów tych informacji (Dz.U. KGP Nr 9, poz. 47).

\section{Opracowania}

Baran T., Grzeszyk C., Młodziejowski B. (1976), Badania kryminalistyczne w archeologii, ,Problemy kryminalistyki”, nr 121-122, s. 268-280.

Bednarek J., Bloch-Bogusławska E., Engelgardt P., Wolska E., Śliwka K. (2005), Wykorzystanie stopnia zrastania szwów czaszkowych do szybkiej śródsekcyjnej oceny wieku osób dorostych, „Archiwum Medycyny Sądowej i Kryminologii” t. 55, s. $185-189$.

Encyklopedia... (1997), Encyklopedia popularna PWN, t. 3, Świat Książki, Warszawa. 
Encyklopedia... (1998), Encyklopedia popularna PWN, t. 5, Świat Książki, Warszawa.

Frątczak-Łagiewska K. (2016), Metody oceny wieku śladów entomologicznych, „Problemy kryminalistyki", nr 293, s. 22-27.

Głosek M. (1996), Archeologiczne aspekty badań cmentarzy polskich oficerów zamordowanych przez NKWD na wschodzie, [w:] Z. Kurnatowska (red.), Stowiańszczyzna w Europie średniowiecznej, Werk, Wrocław, s. 259-266.

Głosek M. (b.d.), W cieniu Lasu Katyńskiego, niepublikowany maszynopis ze zbiorów prof. dr hab. M. Głoska.

Gruza E., Goc M., Moszczyński J. (2008), Kryminalistyka - czyli rzecz o metodach śledczych, Wydawnictwa Akademickie i Profesjonalne, Warszawa.

Kawecki J, Konczewski P., Szwagrzyk K., Trzciński M. (2013), Archeologia sadowa w teorii i praktyce, Wolters Kluwer Polska, Warszawa.

Kempińska-Podhorecka A., Knap O., Parafiniuk M. (2007), Metody Kryminalistyczne w Archeologii - wspótpraca Zakładu Medycyny Sąowej Pomorskiej Akademii Medycznej z Muzeum Archeologicznym w Gdańsku, „Roczniki Pomorskiej Akademii Medycznej w Szczecinie", nr 53, s. 113-121.

Kola A. (2011), Archeologia Zbrodni, Wydawnictwo Naukowe Uniwersytetu Mikołaja Kopernika, Toruń.

Kowal E. (2009), Wybrane metody identyfikacji zwłok ludzkich, [w:] M. Zelka (red.), Taktyka i technika kryminalistyczna - wczoraj, dziś i jutro, KNA „Ad Rem” - WpiA UAM \& KNPK „Iustitia” - WpiA UR, Poznań-Rzeszów, s. 109-115.

Ławecka D. (2010), Wstęp do archeologii, Wydawnictwo Naukowe PWN, Warszawa.

Mańkowska-Pliszka H., Piotrowski J., Niewiadomski L. (2016), Specyficzny przypadek daktyloskopowania zmumifikowanych zwłok, „Problemy kryminalistyki”, nr 292, s. 30-34.

Mazepa J. (2009), Vademecum technika kryminalistyki, Wolters Kluwer Polska, Warszawa.

Muzolf B., Góra M. (1997), Poszukiwania szczątków Stanisława Sojczyńskiego - ,, Warszyca” w tódzkim Brusie. Ciąg dalszy. „Łódzkie Sprawozdania Archeologiczne”, t. 3, s. 159-162.

Nadolski A., Głosek M. (1992), Archeologiczne aspekty akcji badawczej w Charkowie $i$ w Miednoje 25 VII-30 VIII 1991, [w:] M. Tarczyński (red.), Zbrodnia Katyńska. Droga do prawdy, Wojskowe Zakłady Graficzne, Warszawa, s. 248-263.

Rebmann A., David E., Sorg M.H. (2000), Cadaver Dog Handbook. Forensic Training and Tactics for the Recovery of Human Remains, CRC Press, Boca Raton-London-New York-Washington, DC, wersja elektroniczna.

Sojka T. (1977), Adaptacja kryminalistyczna archeologicznych metod wykopaliskowych do lokalizacji mogit masowych, „Studia Kryminologiczne, Kryminalistyczne i Penitencjarne", t. 6, s. 211-232.

Stojer-Polańska J., Lisowicz M., Gołębiowski J. (2015), Kryminalistyczne aspekty poszukiwania zwłok, „Problemy kryminalistyki”, nr 289, s. 3-10. 
Trzciński M. (2005), Współczesne korelacje metodologiczne archeologii i kryminalisty$k i$, [w:] T. Widła (red.), Wokót problematyki dokumentu, Wydawnictwo Uniwersytetu Śląskiego, Katowice, s. 193-198.

Walanus A. (2010), Możliwość wykorzystania izotopu węgla ${ }^{14} \mathrm{C}$ do oceny roku zgonu w zakresie ostatnich 50 lat, „Problemy kryminalistyki”, nr 268, s. 69-70.

\section{SUMMARY}

\section{METHODS USED BY POLISH FORENSICAL AND ARCHAEOLOGICAL SPECIALISTS DURING GRAVES EXCAVATION - DIFFERENCES AND SIMILARITIES}

There seem to be a lot of differences between archaeology and forensic science but, when we take a closer look, we may find out that some methods and goals may be similar, especially on the ground of exhumation of graves. Since the early 90s, in Poland, archaeologists more often started to take part in investigations covering mass murders and crimes against humanity committed during the Second World War. It occurred that their methodology is providing best results in this kind of work. At first, archeologists started only as consultants but then they were given a possibility to lead their own field of excavations in that area of interest. Moreover, it led to creating a new subdiscipline called forensic archaeology. It is hard to tell the difference between archaeological and forensical field methods of exhuming graves. Archaeological literature is way more precise in describing that topic, whereas police experts are thought to provide general procedures of securing a crime scene. The most obvious differences between the two fields in question are visible in the methods of documentation. However, there is no doubt that the specialists in each of the disciplines have learned a lot from each other since they decided to cooperate in some specific cases. 